\title{
PENGARUH MODEL PEMBELAJARAN BERBASIS MASALAH DAN GAYA KOGNITIF SISWA TERHADAP HASIL BELAJAR MATEMATIKA SISWA DI KELAS VIII SMP NEGERI 7 KERINCI
}

\author{
Al Ikhlas \\ Dosen Pendidikan Matematika Sekolah Tinggi Keguruan dan Ilmu Pendidikan (STKIP) \\ Muhammadiyah Wilayah Jambi di Sungai Penuh \\ email: Alikhlas752@gmail.com
}

\begin{abstract}
ABSTRAK
Penelitian ini bertujuan untuk mengetahui pengaruh model pembelajaran berbasis masalah dan gaya kognitif terhadap hasil belajar matematika siswa, korelasi antara gaya kognitif terhadap hasil belajar matematika siswa, dan pengaruh interaksi antara penggunaan model pembelajaran dan gaya kognitif siswa terhadap hasil belajar matematika siswa di kelas VIII (Delapan) SMP Negeri 7 Kerinci tahun pelajaran 2016/2017. Penelitian ini dilakukan dengan metode penelitian eksperimen semu dengan menerapkan desain faktorial $2 \times 2$. Populasi penelitian adalah siswa SMP Negeri 7 Kerinci Kelas VIII Semeseter genap tahun pelajaran 2016/2017. Sampel penelitian terdiri dari kelas eksperimen berjumlah 32 orang siswa dan kelas kontrol berjumlah 31 orang siswa. Pengumpulan data dilakukan menggunakan dua macam instrumen yakni intrumen Group Embedded Figures Test (GEFT) untuk mengukur gaya kognitif siswa dan instrumen tes hasil belajar matematika siswa dalam bentuk essay. Hasil analisis data dan uji statistik menunjukkan bahwa model pembelajaran berbasis masalah dan gaya kognitif berpengaruh terhadap hasil belajar matematika, terdapat korelasi antara gaya kognitif terhadap hasil belajar matematika, tidak terdapat interaksi antara model pembelajaran dan gaya kognitif terhadap hasil belajar matematika siswa. Berdasarkan hasil penelitian tersebut disarankan kepada guru, khususnya guru matematika agar penerapan model pembelajaran berbasis masalah dikembangkan sebagai satu inovasi dalam proses belajar mengajar.
\end{abstract}

\section{Kata Kunci : Model Pembelajaran Berbasis Masalah, Konvensional, Gaya Kognitif dan Hasil Belajar.}

\section{PENDAHULUAN}

Pembelajaran matematika di sekolah memiliki empat tujuan utama yaitu : (1) Melatih cara berpikir dan bernalar dalam menarik kesimpulan, (2) Mengembangkan aktivitas kreatif yang melibatkan imajinasi, intuisi, dan penemuan dengan mengembangkan pemikiran divergen, originil, rasa ingin tahu, prediksi dan dugaan serta mencoba-coba, (3) Mengembangkan kemampuan pemecahan masalah dan (4) Mengembangkan kemampuan menyampaikan informasi dan mengkomunikasikan gagasan. (Depdiknas, 2006).

Paradigma pembelajaran telah bergeser dari paradigma lama (behavioristik) ke paradigma baru (konstruktivistik). Perubahan paradigma belajar tersebut terjadi perubahan fokus yang selama ini pembelajaran yang berfokus pada guru dan dosen (teacher centered) kepeada pembelajaran yang berfokus pada peserta didik (student centered). Pergeseran ini berdasarkan pada penelitian para ahli, faktor psikologis, perkembangan pembelajaran, dan kebutuhan peserta didik akan pengembangan dirinya. 
Namun demikian, behavioristik bukan ditinggalkan sama sekali, akan tetapi behavioristik akan masih diterapkan pada karyawan industri, karyawan kantor, militer dan lain sebagainya untuk menciptakan prilaku yang seragam.

Temuan dilapangan sikap tanggung jawab siswa dalam pembelajaran terkadang kurang misalnya dalam melaksanakan tugas individu, masih ada yang menyontek. Siswa yang mempunyai sikap ilmiah yang tinggi akan memiliki kelancaran dalam berpikir sehingga siswa akan termotivasi untuk selalu berprestasi dan memiliki komitmen yang kuat untuk mencapai keberhasilan dan keunggulan. Dapat diasumsikan jika sikap ilmiah siswa sangat baik dalam pembelajaran matematika maka akan memiliki kelancaran berpikir sehingga hasil belajar siswa dapat meningkat. Untuk itu perlunya pertimbangan bagi guru akan hakikat mata pelajaran matematika dalam melaksanakan pembelajaran kepada siswa. Aktivitas siswa untuk bertanya, menjawab dan mengajukan pendapat, sangat kurang pada saat pembelajaran berlangsung, sehingga nilai ujian mid semester ganjil matematika siswa tahun pelajaran 2016/2017 masih dibawah KKM.

Seorang guru juga harus mempunyai kemampuan mengajar sesuai dengan bidang studinya, contohnya seorang guru matematika mampu menggunakan suatu model dalam bidang matematika dengan baik dan benar karena ia menguasai tekniknya". Karena model pembelajaran merupakan hal yang cukup berpengaruh terhadap hasil pembelajaran matematika diantara banyak pengaruh lain. Mengingat pentingnya peranan matematika yang berfungsi sebagai penunjang yang dapat dipergunakan dalam berbagai ilmu pengetahuan dan kehidupan, maka para siswa perlu memiliki penguasaan matematika yang memadai sehingga perlu dicari solusi untuk meningkatkan hasil belajar siswa.

Berdasarkan permasalahan yang telah dikemukakan dibutuhkan suatu model pembelajaran, agar proses pembelajaran matematika lebih menyenangkan, bermanfaat dan diharapkan dapat meningkatkan pemahaman serta bisa mengaktifkan siswa dalam pembelajaran. Model mengajar yang baik adalah model yang dapat menumbuhkan kegiatan belajar siswa.

Menurut Suhana (2014:37) model pembelajaran merupakan salah satu pendekatan dalam rangka mensiasati perubahan perilaku peserta didik secara adaptif maupun generatif. Model pembelajaran sangat erat kaitannya dengan gaya belajar peserta didik (learning style) dan gaya mengajar guru (teaching learning), yang keduanya disingkat menjadi SOLAT (Style Of Learning and Teaching).

Model pembelajaran konvensional yang digunakan oleh guru sebagian besar kurang sesuai dengan tuntutan kurikulum, karena pembelajaran yang dilakukan kurang memberi kesempatan seluas-luasnya bagi siswa untuk aktif mengkonstruksikan pengetahuan dan keterampilannya serta kurang mempertimbangkan hakikat gaya belajar siswa. Model pembelajaran yang mampu mengantisipasi kelemahan model pembelajaran konvensional adalah dengan menggunakan model pembelajaran yang pendekatannya berpusat pada siswa, diantaranya adalah model pembelajaran berbasis masalah.

Model pembelajaran berbasis masalah adalah suatu pembelajaran dimana masalah digunakan secara langsung sebagai alat untuk membantu siswa memahami materi 
pelajaran yang sedang mereka pelajari. Jones, Rasmussen, and Moffit dalam (Yamin, 2013:63) Pembelajaran berbasis masalah (PBL) lebih menekan pada pemecahan masalah secara autentik seperti masalah yang terjadi dalam kehidupan sehari-hari.

Kosasih (2015:88) menyatakan pembelajaran berbasis masalah (Problem base learning) adalah model pembelajaran yang berdasarkan pada masalah-masalah yang dihadapi siswa terkait dengan KD yang dipelajari siswa. Masalah yang dimaksud bersifat nyata atau sesuatu yang menjadi pertanyaan-pertanyaan pelik bagi siswa.

Dari beberapa pendapat di atas dapat disimpulkan bahwa model pembelajaran berbasis masalah merupakan salah satu model pembelajaran yang menyajikan masalah kontekstual sehingga meransang peserta didik untuk belajar lebih aktif.

Dengan model pembelajaran berbasis masalah siswa dihadapkan pada berbagai masalah yang dijadikan bahan pembelajaran secara langsung agar siswa menjadi peka dan tanggap terhadap semua persoalan yang dihadapinya dalam kehidupan sehari-hari. Pembelajaran matematika yang menggunakan model pembelajaran berbasis masalah adalah bersifat umum dan lebih mengutamakan kepada proses dari pada hasil. Proses merupakan faktor utama dalam pembelajaran berbasis masalah, bukan produk seperti yang dijumpai pada pembelajaran selama ini. Pengertian proses dalam hal ini ialah ketika siswa belajar matematika ada proses reinvention menemukan kembali, artinya prosedur, aturan yang dipelajari tidaklah disediakan dan diajarkan oleh guru dan siswa siap menerima apa yang dijelaskan oleh guru, tetapi siswa harus ikut terlibat aktif dan mengkonstruksi pengetahuannya sendiri. Dalam penerapan model pembelajaran berbasis masalah disajikan permasalahan-permasalahan untuk memancing kreativitas berpikir siswa.

Pembelajaran berbasis masalah dapat diterapkan bila didukung lingkungan belajar yang konstruktivistik mencakup beberapa faktor, menurut Jonassen (Yamin:2013:63) kasus-kasus berhubungan, fleksibelitas kognisi, sumber-sumber informasi, piranti kognitif, pemodelan yang dinamis, percakapan dan kolaborasi, dan dukungan social dan kontektual. Dengan demikian, PBL menciptakan (1) menciptakan pembelajran yang bermakna, dimana peserta didik dapat memecahkan masalah yang mereka hadapi dengan cara mereka sendiri sesuai dengan pengetahuan dan pengalamannya, (2) dapat mengintegrasikan pengetahuan dan keterampilan secara simultan dan mengaplikasikannya dalam konteks yang relevan, (3) dapat meningkatkan kemampuan berpikir kritis, menumbuhkan inisiatif peserta didik dalam bekerja, motivasi internal untuk belajar, dan dapat mengembangkan hubungan interpersonal dalam bekerja kelompok.

Dalam penerapan model pembelajaran berbasis masalah matematika terbuka siswa diharapkan akan aktif mencari dan menemukan solusi dari permasalahan yang diberikan, sehingga akan dapat mengembangkan kemampaun pemecahan masalah matematika siswa. Akan tetapi penerapan model pembelajaran berbasis sangatlah perlu memperhatikan faktor lain yang berpengaruh terhadap kemampuan pemecahan masalah siswa. Salah satu faktor yang berpengaruh terhadap kemampuan pemecahan masalah siswa dan berasal dari dalam diri siswa adalah gaya kognitif siswa.

Salah satu karakteristik siswa adalah gaya belajar siswa. Gaya belajar merupakan cara yang khas dimiliki seseorang dalam belajar. Gaya belajar meliputi 
beberapa komponen, antara lain : tipe belajar dan gaya kognitif (Rahman, 2008:454).

Menurut Ngilawajan (2013:73) gaya kognitif merupakan cara seseorang memproses, menyimpan maupun menggunakan informasi untuk menanggapi suatu tugas atau berbagai jenis lingkungannya. Rahman (2008:455) juga mengemukakan gaya kognitif adalah cara yang khas yang digunakan seseorang dalam mengamati dan beraktivitas mental dibidang kognitif. Gaya kognitif adalah suatu cara yang konsisten yang dilakukan oleh siswa dalam menangkap stimulus atau informasi, cara mengingat berpikir dan memecahkan permasalahan. Dengan kata lain setiap siswa memiliki cara yang relatif tetap atau konsisten dalam mengolah informasi, berpikir dan mengingat.

Menurut Rahmatika (2014:64) gaya kognitif merupakan salah satu ide baru dalam kajian psikologi perkembangan dan pendidikan. Ide ini berkembang pada penelitian bagaimana individu menerima dan mengorganisasi informasi dari lingkungan sekitarnya. Sebagai seorang guru haruslah mengerti akan adanya keterkaitan antara kreativitas yang dihasilkan dari masing-masing gaya kognitif tersebut.

Gaya kognitif siswa perlu disesuaikan dengan gaya mengajar guru. Salah satu dimensi gaya kognitif adalah Field Independent (FI) dan Field Dependent (FD). Gaya kognitif FI Menurut Arends (Sulani, 2014:10) melihat bagian-bagian secara terpisah, memiliki kemampuan analitis kuat, dan lebih memantau pemprosesan informasi dari pada berhubungan dengan orang lain, sedangkan gaya kognitif FD menganggap situasi secara keseluruhan, melihat gambaran masalah yang paling besar, impersonal, mementingkan hubungan soaial dan bekerja baik dalam kelompok.

Dari uraian tersebut dapat disimpulkan bahwa gaya kognitif adalah cara setiap individu dalam menerima, mengorganisasikan, merespon, mengolah informasi dan menyusunnya berdasarkan pengalaman-pengalaman yang dialami berdasarkan kajian psikologis.

Penelitian Putra (2013) mengenai hubungan gaya kognitif dan prestasi belajar menunjukkan bahwa terdapat korelasi positif dan secara statistik signifikan antara gaya kognitif dan prestasi belajar. Selain itu, penelitian Una (2013) menyimpulkan bahwa terdapat hubungan positif antara gaya kognitif siswa dengan hasil belajar matematika. Hal ini berarti semakin tinggi gaya kognitif siswa (semakin banyak siswa yang memilki gaya kognitif FI yaitu gaya kognitif yang cenderung menyukai analisis dan pemecahan masalah), maka semakin tinggi pula hasil belajar siswa pada mata pelajaran matematika. Pada penelitian sebelumnya, aspek yang diteliti focus pada aspek prestasi belajar dan hasil belajar matematika secara umum, tetapi belum spesifik meneliti salah satu aspek kemampuan khusus dalam matematika, yaitu kemampuan pemecahan masalah.

Husdarta (2010:24) mengemukakan gaya belajar kognitif dapat dibagi menjadi tiga tipe siswa dalam belajar. Ketiga tipe tersebut terdiri dari Field depence, Field indepence, impulsif-refleksif, dan preseptif/reseptif-sistematis/intuitif. Dalam penelitian 
ini, peneliti memilihi fokus pada tipe gaya kognitif FI dan FD. Perbedaan mendasar dari kedua gaya kognitif tersebut yaitu dalam hal bagaimana melihat suatu permasalahan. Berdasarkan beberapa penelitian dibidang psikologi, ditemukan bahwa individu dengan gaya kognitif FI cenderung lebih analitis dalam melihat suatu masalah dibandingkan individu dengan gaya kognitif FD. Karakteristik dasar dari kedua gaya kognitif tersebut sangat cocok untuk diterapkan dalam penelitian yang melibatkan proses berpikir dalam pemecahan masalah matematika. Selain itu karakteristik kedua gaya kognitif tersebut sesuai dengan kondisi banyak siswa yang ditemui penulis dilapangan sehingga hal ini menjadi alasan bagi penulis untuk memilih gaya kognitif FI dan FD sebagai fokus penelitian.

Witkin telah mengembangkan suatu instrumen berupa gambar sederhana dalam suatu pola yang kompleks. Instrumen yang dimaksud disebut dengan istilah Group Embedded Figures Test (GEFT). Dengan instrumen ini dapat diketahui jenis gaya kognitif siswa apakah gaya FI atau FD. Berdasarkan fenomena tersebut, penulis tertarik untuk mengadakan penelitian tentang penerapan model pembelajaran berbasis masalah ditinjau dari gaya kognitif siswa untuk meningkatkan hasil belajar siswa.

Melalui model pembelajaran berbasis masalah, siswa akan dilibatkan secara aktif dalam proses pembelajaran melalui kegiatan diskusi secara mendalam yang dapat mengantarkan siswa untuk sampai pada konsep matematika yang benar serta dapat membentuk siswa secara aktif dalam menyelesaikan permasalahan yang dihadapi. Melalui model pembelajaran berbasis masalah maka diharapkan dapat memfasilitasi siswa untuk meningkatkan kemampuannya melalui pengkonstruksian pengetahuan yang lebih bermakna. Model pembelajaran berbasis masalah jika dikolaborasikan dengan masalah matematika terbuka diduga akan memiliki pengaruh yang baik terhadap kemampuan pemecahan masalah siswa. Dengan model pembelajaran berbasis maslah matematika terbuka memungkinkan siswa untuk dapat kesempatan dalam menggunakan pengetahuan dan keterampilan matematikanya dan siswa akan aktif mencari dan menemukan solusi dari permasalahan yang diberikan, sehingga akan dapat mengembangkan kemampuan pemecahan masalah matematika siswa. Begitu juga dengan gaya kognitif, siswa memiliki gaya kognitif yang berbeda antara gaya kognitif tinggi dan gaya kognitif rendah. Oleh karena itu penulis tertarik untuk mengadakan penelitian tentang "Pengaruh model pembelajaran berbasis masalah dan gaya kognitif terhadap hasil belajar matematika siswa di kelas VIII SMP Negeri 7 Kerinci”.

\section{METODE PENELITIAN}

Penelitian ini dilaksanakan di SMP Negeri 7 Kerinci dengan subjek penelitian adalah siswa kelas VIII (Delapan). Penelitian ini dilaksanakan pada semester genap tahun pelajaran 2016/2017 dari bulan januari sampai dengan februari 2017.

Penelitian dilaksanakan dengan menerapkan desain faktorial. Rancangan yang digunakan dalam penelitian ini adalah rancangan faktorial 2 X 2 . 
Pengambilan sampel dilakukan secara purposive. Sampel dibagi menjadi 2 kelompok yaitu kelompok eksperimen dan kelompok kontrol. Pengambilan data gaya kognitif siswa dilakukan dengan tes kemampuan kognitif dari Group Embedded Figures Test (GEFT). Dalam hal ini siswa dikategorikan menjadi 2 kelompok yaitu kelompok siswa dengan gaya kognitif FI (Field Independent) dan kelompok siswa dengan gaya kognitif FD (Field Dependent); Kelompok eksperimen diberikan pembelajaran dengan model pembelajaran berbasis masalah, sedangkan kelompok kontrol diberikan model pembelajaran konvensional; Melakukan tes kemampuan belajar sebelum dan sesudah pelaksanaan pembelajaran. Data yang diperoleh kemudian dianalisis untuk melihat adanya perbedaan antara hasil belajar kelas eksperimen dan kelas control.

\section{HASIL DAN PEMBAHASAN}

Setelah dilakukan proses bembelajaran dengan menerapkan model pembelajaran berbasis masalah untuk kelas eksperimen dan model pembelajaran konvensional untuk kelas kontrol pada siswa dikelas VIII SMP Negeri 7 Kerinci tahun pelajaran 2016/2017, untuk kelas eksperimen diperoleh hasil yang lebih tinggi dibandingkan kelas kontrol. Hal ini dibuktikan dengan analisis data postes kelas eksperimen menunjukkan angka rata-rata 76,28 dan kelas kontrol 62,74. Hasil analisis memperlihatkan bahwa nilai postes kelas eksperimen lebih tinggi dibandingkan kelas kontrol. Jadi kelas eksperimen dengan penerapan model pembelajaran berbasis masalah dalam proses pembelajaran memberikan hasil belajar yang lebih tinggi bila dibandingkan dengan penggunaan model konvensional.

Model pembelajaran berbasis masalah merupakan salah satu model pembelajaran yang menyajikan masalah kontekstual sehingga meransang peserta didik untuk belajar. Dalam penelitian ini pengaruh implementasi model pembelajaran berbasis masalah pada pokok bahasan lingkaran dianalisis dari temuan dan didapatkan kesimpulan dan prediksi pada kelompok siswa yang memiliki kaya kognitif Field Independent dan Field Dependent. Hasil penelitian kelompok siswa yang memiliki gaya kognitif Field Independent ternyata memperoleh hasil belajar lebih tinggi dibanding siswa yang memiliki gaya kognitif Field dependent.

Berdasarkan kejadian tersebut guru perlu memahami aspek dari gaya kognitif siswa demi mencapai hasil belajar yang lebih maksimal atau setidaknya sama atau diatas KKM. Kemudian guru juga perlu memahami pergeseran paradigma proses pendidikan, yaitu paradigma pembelajaran yang semula berpusat kepada guru beralih pada paradigm pembelajaran yang berpusat pada siswa, salah satu bentuk model pembelajaran yang dapat dilakukan adalah model pembelajaran berbasis masalah.

Berdasarkan temuan penelitian, terdapat pengaruh gaya kognitif siswa terhadap hasil belajar matematika siswa. Dimana siswa yang memiliki gaya kognitif FI hasil belajarnya lebih tinggi dibandingkan dengan siswa yang memiliki gaya kognitif FD. Hal ini dibuktikan dengan analisis data data postes, dimana siswa yang memiliki gaya kognitif Field Independent nilai rata-rata hasil belajarnya lebih tinggi dibandingkan 
nilai rata-rata hasil belajar matematika siswa yang memiliki gaya kognitif field Dependent.

Kedua gaya kognitif ini memberikan ciri yang berbeda pada gaya belajar seseorang. Witkin, dkk (Candiasa, (Hikmawati, 2013:116)) mengklasifikasi beberapa karakteristik individu yang memiliki gaya kognitif field independent, anatara lain: (1). Memiliki kemampuan menganalisis untuk memisahkan objek dari lingkungan sekitar, sehingga persepsinya tidak terpengaruh bila lingkungan mengalami perubahan; (2). Mempunyai kemampuan mengorganisasi objek-objek yang belum teroraganisir dan mengorganisir objek-objek yang sudah terorganisir; (3). Cenderung kurang sensitif, dingin, serta menjaga jarak dengan orang lain, dan individualistis; (4). Memilih profesi yang dilakukan secara individu dengan materi yang lebih abstrak atau memerlukan teori analisis; (5). Cenderung mendefinisikan sendiri, dan (6). Cenderung mbekerja dengan memntingkan motivasi instrinsik dan lebih dipengaruhi oleh penguatan instrinsik. Dari karakteristik tersebut dapat diketahui bahwa individu yang memiliki gaya kognitif field independent mempunyai kecenderungan dalam respom stilmulus menggunakan persepsi yang dimilikinya sendiri dan lebih analisis.

Seseorang dengan gaya kognitif field independent cenderung menyatakan suatu gambaran lepas dari gambaran latar belakang tersebut, serta mampu membedakan objek-objek dari konteks sekitarnya lebih mudah, mereka mampu dengan mudah menghadapi tugas-tugas yang memerlukan perbedaan-perbedaan dan analisis. Dalam proses pembelajaran, individu yang memiliki gaya kognitif field independent cenderung belajar mandiri dengan merumuskan sendiri tujuan pembelajaran, lebih mementingkan motivasi dan penguatan instrinsik, serta mampu menyesuaikan organisasi materi pembelaran.

Sedangkan siswa yang memiliki gaya kognitif field dependent menurut witkin, dkk (Hikmawati, 2013:117) memiliki beberapa karakteristik antara lain : (1) cenderung berpikir global, memandang objek sebagai satu kesatuan dengan lingkungannya, sehingga persepsinya mudah terpengaruh oleh perubahan oleh perubahan lingkungan; (2). Cenderung menerima struktur yang sudah ada karena kurang memiliki kemampuan merestrukturisasi; (3). Memiliki orientasi sosial, sehingga tampak baik hati, baik hati, ramah, bijaksana, baik budi dan penuh kasih sayang terhadap kasih sayang terhadap individu lain; (4). Cenderung memilih profesi yang menekan pada keterampilan sosial; (5). Cenderung mengikuti tujuan yang sudah ada; dan (6). Cenderung bekerja dengan mengutamakan motivasi eksternal dan lebih tertarik pada penguatan eksternal, berupa hadiah, pujian, atau dorongan dari orang lain.

Seseorang yang memiliki gaya kognitif field dependent menerima suatu secara global, mengalami kesulitan dalam memisahkan diri dari kedaan sekitarnya, lebih menginginkan lingkungan yang terstruktur, mengikuti tujuan yang sudah ada, serta mengutamakan motivasi dan penguatan eksternal.

Berdasarkan temuan penelitian ini serta uraian yang telah dipaparkan, maka cukup beralasan untuk merekomendasikan, agar dalam pembelajaran matematika diperlukan adanya kerjasama dalam bentuk koperatif antara siswa field independent dan field dependent. Dalam kaitan ini hendaknya guru dalam dalam membagi kelompok belajar 
memperhatikan keanggotaan kelompok yang terdiri dari field independent dan field dependent. Selain itu guru hendaknya dalam pembelajaran matematika memberikan permasalahan yang berkaitan dengan dunia nyata siswa, karena pada umumnya siswa tingkat menengah pertama gaya berpikirnya masih dalam kategori sekuensial konkrit dan acak abstrak, sehingga mereka dalam belajar matematika yang abstrak masih memerlukan manipulasi bneda-benda konkrit.

Berdasarkan hasil penelitian dapat disimpulkan bahwa tidak terdapat interaksi atau hubungan antara model pembelajaran dan gaya kognitif siswa terhadap hasil belajar matematika siswa. Dari uji hipotesis dapat dilihat bahwa gaya kognitif tidak mempengaruhi hubungan model pembelajaran terhadap hasil belajar matematika.

Menurut Ghozali (Rufi'i, 2011:13) mengemukakan bahwa pengaruh interaksi adalah pengaruh bersama dua atau lebih variabel bebas terhadap variabel terikat. Berkaitan dengan pengaruh interaksi, Hair, dkk (Rufi'i, 2011:13) mengemukakan interkasi dapat terjadi apabila variabel-variabel bebas tidak membawa akibat-akibat secara terpisah dan sendiri-sendiri. Sebaiknya interaksi dapat pula tidak terjadi jika lebih dari satu varuabel bebas membawa akibat-akibat terpisah yang signifikan.

\section{KESIMPULAN}

Berdasarkan hasil penelitian yang telah dilaksanakan, dapat disimpulkan bahwa:

1. Terdapat pengaruh model pembelajaran berbasis masalah dan gaya kognitif terhadap hasil belajar matematika siswa pada materi Lingkaran di kelas VIII SMP Negeri 7 Kerinci.

2. Terdapat korelasi antara gaya kognitif siswa terhadap hasil belajar matematika siswa pada materi Lingkaran di kelas VIII SMP Negeri 7 Kerinci.

3. Terdapat perbedaan hasil belajar matematika siswa yang memiliki gaya kognitif FI yang dibelajarkan dengan model pembelajaran berbasis masalah dengan siswa yang memiliki gaya kognitif FI yang dibelajarkan dengan model pembelajaran konvensional.

4. Terdapat perbedaan hasil belajar matematika siswa yang memiliki gaya Kognitif FD yang dibelajarkan dengan model pembelajaran berbasis masalah dengan siswa yang memiliki gaya Kognitif FD yang dibelajarkan dengan model pembelajaran konvensional.

5. Tidak terdapat interaksi antara model pembelajaran dan gaya kognitif siswa dalam mempengaruhi hasil belajar matematika siswa pada materi Lingkaran di kelas VIII SMP Negeri 7 Kerinci.

\section{DAFTAR PUSTAKA}

Aprianti, M., 2015, Pengaruh strategi pembelajaran yang berorientasi pada masalah matematika di tinjau dari keterampilan metakognisi siswa SMP Negeri 24 Kota Jambi tahun 2015, makalah disajikan pada seminar Nasional Pendidikan Matematika 2015 yang bertema "Revolusi mental melalui pendidikan hati untuk mewujudkan 
pembelajaran matematika yang menyenangkan", Mei 16, Palembang, Universitas Sriwijaya Fakultas Keguruan dan Ilmu Pendidikan.

Depdiknas. 2006. Permen 22 Th.2006-Standar Isi, Standar Kompetensi dan Kompetensi Dasar Matematika SMA-MA. Jakarta: Dirjen Manajemen Pendidikan Dasar dan Menengah, Diknas.

Hikmawati, 2013, Pengaruh penggunaan media pembelajaran dan gaya kognitif terhadap hasil belajar matematika siswa kelas VIII Madrasah Tsanawiyah, Tesis, Universitas Jambi, Jambi.

Husdarta, J. Y. M., 2013. Belajar dan pembelajaran pendidikan jasmani dan kesehatan. Bandung: ALFABETA.

Kosasih., 2015. Strategi belajar dan pembelajaran implementasi kurikulum 2013. Bandung: YRAMA WIDYA.

Ngilawajan, D. A., 2013. Proses berpikir siswa dalam memecahkan masalah matematika materi turunan ditinjau dari gaya kognitif Field independent dan field dependent. Pedagogia, 2(1): 73-74.

Rahmatika, S., 2014. Tingkat berpikir kreatif siswa dalam menyelesaikan masalah matematika berdasarkan gaya kognitif refleksif dan impulsif. Didaktik matematika, 1(1): 64 .

Rahman, A., 2008. Analisis hasil belajar matematika berdasarkan perbedaan gaya kognitif secara psikologis dan konseptual tempo pada siswa kelas X SMA Negeri 3 Makassar. Jurnal pendidikan dan kebudayaan, 14(072): 454-460.

Putra, A., Murti, B., dan Suriyasa, P. 2013. "Hubungan Gaya Kognitif dan Penalaran Verbal dengan Prestasi Belajar Mata Kuliah Anatomi II pada Mahasiswa Pendidikan Jasmani Kesehatan dan Rekreasi (Fakultas Olahraga Dan Kesehatan Universitas Pendidikan Ganesha)”. Jurnal Magister Kedokteran Keluarga, Volume 1 No. 1 pp. 92-103.

Rufi'i, 2011, Pengaruh strategi pembelajaran dan gaya kognitif terhadap perolehan belajar prosedur statistika, Tesis, Universitas PGRI Adi Buana Surabaya, Jawa Timur.

Suhana, C., 2014. Konsep Strategi Pembelajaran. Bandung: Refika Aditama.

Sulani, P., 2014. Pengaruh strategi pembelajaran dan gaya kognitif terhadap kemampuan berpikir kritis siswa dalam pembelajaran sejarah. Pendidikan Sejarah, 3(2): 10-15.

Una, M. 2013. "Hubungan antara Gaya Kognitif Siswa dengan Hasil Belajar Matematika (Suatu Penelitian Survei dengan Pendekatan Korelasional pada Siswa VIII di SMP Negeri 1 Tilong Kabila Tahun Pelajaran 2012-2013)". Skripsi. Gorontalo: Universitas Negeri Gorontalo.

Yamin, M. 2013. Desain Baru Pengajaran Konstruktivistik. Jambi: Referensi. 